\title{
ZC3H12A Gene
}

National Cancer Institute

\section{Source}

National Cancer Institute. ZC3H12A Gene. NCI Thesaurus. Code C148595.

This gene is involved in ribonuclease activity and transcriptional regulation. 